\title{
Konflik Pengangkatan Penghulu Suku Koto di Nagari Kapalo Hilalang, Kabupaten Padang Pariaman
}

\author{
Meitya Riani Sabella, Nurman S \\ Prodi Pendidikan Pancasila dan Kewarganegaraan \\ FIS Universitas Negeri Padang \\ E-mail: meityariani48@gmail.com
}

\section{ABSTRAK}

Artikel ini mendeskripsikan konflik yang terjadi dalam prosesi pengangkatan penghulu suku koto di Nagari Kapalo Hilalang Kecamatan 2X11 Kayu Tanam, Kabupaten Padang Pariaman. Langkah-langkah yang dilakukan dalam prosesi pengangkatan penghulu yaitu; (1) musyawarah satu nenek (saanduang), (2)musyawarah kaum, (3) bagatok pinang (pengesahan gelar) dan (4) alek Datuak (peresmian gelar Datuk). Namun pengangkatan penghulu ini ditunda karena adanya pihak yang tidak setuju dengan datuk yang telah disahkan. Metode penelitian yang digunakan adalah deskriptif dengan pendekatan kualitatif. Informan penelitian adalah Wali Nagari, Ketua dan anggota KAN, Niniak Mamak dan anggota kaum suku koto. Teknik pengumpulan data yaitu teknik wawancara dan teknik studi dokumentasi. Hasil penelitian menunjukan bahwa KAN tidak menjalankan perannya sebagai penengah ketika terjadi konflik di dalam suatu kaum.

Kata Kunci: konflik, adat, penghulu, suku koto, KAN

\section{ABSTRACT}

This article describes the conflict that occurred in the procession of appointing penghulu (leader) of koto in Nagari Kapalo Hilalang, 2X11 Kayu Tanam District, Padang Pariaman Regency. The steps that taken in the appointment procession of the penghulu are; (1) the discussion of one grandmother (saanduang), (2) the discussion in clan groupe, (3) the certification of the title (bagatok pinang) and (4) alek Datuak (inauguration of the title of Datuk). However, the appointment of the penghulu was postponed because there were parties who did not agree with the legitimate datuk. The research method used is descriptive with a qualitative approach. Research informants were Wali Nagari, Chairman and members of KAN, Niniak Mamak and members of the koto tribe. Data collection techniques are interview and documentation. The results showed that KAN did not carry out its role as a mediator when there was a conflict within a tribe.

Keywords: conflict, custom, penghulu, koto tribe, village custom organization 


\section{PENDAHULUAN}

Pemilihan pemimpin adat di Indonesia rentan mengalami konflik. Konflik adalah pertentangan antar individu atau kelompok sosial yang terjadi karena perbedaan kepentingan. Hal ini seringkali disertai dengan adanya ancaman atau kekerasan (Soekanto, 2014). Konflik perebutan gelar terjadi di beberapa wilayah di Indonesia, seperti di Keraton Yogyakarta. Sultan Hamengkubuwono $X$ hanya memiliki anak perempuan dan dalam peraturan keraton perempuan tidak bisa menjadi pemimpin. Namun, Sultan tetap menginginkan anak pertamanya menjadi penerus kerajaan. Konflik terjadi ketika seharusnya tahta kerajaan digantikan oleh adik Sultan yang laki-laki, namun Sultan Hamengkubuwono $X$ tidak mengindahkan aturan tersebut (Safitri, 2019).

Di Minangkabau juga terdapat berbagai kasus konflik pemilihan pemimpin adat. Salah satunya adalah konflik yang disebabkan karena adanya kelompok yang memisahkan diri dari kepemimpinan lama kemudian membentuk kepemimpinan baru. Konflik ini terjadi pada perebutan posisi penghulu suku Melayu di Nagari Sialang Gaung, Kecamatan Koto Baru, Kabupaten Dharmasraya (Lasmita,2019). Kemudian konflik yang terjadi dalam kepengurusan Kerapatan Adat Nagari (KAN) Lubuk Kilangan yang berawal dari perebutan kewenangan antar Ninik Mamak dalam struktur kepengurusan (Rahmat, 2020).

Kemudian konflik lainnya adalah perebutan gelar yang saling menghalangi antara kaum sabarek sapikua untuk melaksanakan proses pengangkatan penghulu di Nagari Paninjauan Kecamatan $X$ Koto Kabupaten Tanah Datar (Hafid, 2016). Contoh kasus lainnya yang juga terjadi di Sumatera Barat adalah konflik sengketa lahan antara mamak dengan mamak yang membuat hubungan sesama pemimpin adat menjadi rusak. Konflik ini juga mengakibatkan pembatasan keterlibatan dalam kegiatan-kegiatan masyarakat (Sari, 2014).

$$
\text { Rata-rata kasus di }
$$

Minangkabau adalah perebutan gelar penghulu. Penghulu di Minangkabau memiliki fungsi dan peranan yang sangat penting karena mereka dipilih oleh kaumnya. Kepemimpinan mereka diibaratkan dengan kata adat "baringin gadang di tangah koto akanyo tampek basanda dahannyo tampek bagantuang daunnyo tampek bataduah kalau kehujanan tampek balinduang kalau kapanehan" (baringin besar ditengah kampung akarnya tempat bersandar dahannya tempat bergantung daunnya tempat berteduh di kala kehujanan tempat berlindung kala kepanasan (Afandy, 2016).

Di Minangkabau sendiri terdapat dua tradisi dalam memperoleh pemimpin adat, yaitu menggunakan sistem kelarasan Koto Piliang dan Bodi Chaniago. Berdasarkan sistem kelarasan Koto Piliang, persayaratan mengangkat Penghulu berdasarkan keturunan langsung dari mamak kandung atau saudara ibu. Sedangkan pada laras Bodi Caniago, seorang Penghulu adalah laki-laki yang berada di bawah satu payung suku dan diangkat secara bergilir (Marthala, 2014).

Konflik yang terjadi di Nagari Kapalo Hilalang yang menjadi 
pembahasan dalam artikel ini disebabkan adanya tindakan mengahalangi dari sebagian pihak dalam kaum sehingga sulitnya mendapatkan kesepakatan. Di Nagari ini gelar pemimpin adat mengacu kepada kata adat "gadang balega kayo basalin" yang berarti bahwa seorang penghulu dipilih dan diangkat secara bergilir berdasarkan syarat tertentu. Namun tidak selalu prosesi pengangkatan penghulu dapat berjalan dengan lancar disebabkan pentingnya gelar pusaka ini.

Artikel ini akan menganalisis permasalahan dalam prosesi pengangkatan penghulu suku koto di Nagari Kapalo Hilalang Kecamatan 2x11 Kayu Tanam Kabupaten Padang Pariaman dan upaya KAN dalam menyelesaikan tersebut.

\section{HASIL DAN PEMBAHASAN}

Terdapat empat langkah prosesi pengangkatan penghulu, yaitu; (1) Musyawarah saanduang. Musyawarah saanduang yaitu musyawarah yang dilakukan oleh satu keluarga yang berasal dari satu nenek, mamak pusako atau mamak rumah. Mamak ini memimpin musyawarah untuk memilih calon penghulu, panungkek, labai, dan urang tuo, yang sesuai alur dan patut. Pengangkatan ini dilakukan berdasarkan kata adat: gadang balega kayo basalin yaitu sesuai dengan giliran pihak keluarga yang berhak. Kemudian ditunjuk salah satu nama dan dilihat perilakunya, keturunan, serta yang sesuai alur dan patut. Jika sudah mendapatkan kata mufakat atau kata yang bulat, selanjutnya hasil musyawarah saanduang tersebut dibawa ke dalam musyawarah sekaum.
(2) Musyawarah kaum. Setelah mendapatkan kata sepakat dari musyawarah saanduang, dilanjutkan dengan musyawarah kaum. Pemilihan ini dilakukan di surau kaum. Para pemimpin yang telah disepakati di dalam musyawarah saanduang kembali dirapatkan pada kaum senagari.

(3) Bagatok Pinang. Setelah semua pihak sepakat dengan calon penghulu dan perangkatnya, maka dilanjutkan dengan acara bagatok pinang. Pada saat bagatok pinang seluruh penghulu pucuk se nagari hadir, dan masyarakat kaum suku koto baik lakilaki maupun perempuan juga turut hadir. Pada saat bagatok pinang calon penghulu suku Koto disahkan oleh Ketua KAN, kemudian ketua KAN menyampaikan bahwa penghulu suku koto yang baru tersebut sudah bisa mengurusi kemenakan dan kaumnya. Sikap ini diistilahkan dengan kata adat: pai tampek batanyo, pulang babarito. Pada bagatok pinang ketua KAN telah menyetujui untuk selanjutnya didirikan alek datuak pada kaum suku koto.

4. Alek Datuk. Setelah prosesi bagatok pinang, ketua KAN menyampaikan tanggal peresmian gelar alek datuk. Ketua KAN meminta masyarakat kaum dari penghulu baru untuk mempersiapkan semua keperluan untuk alek datuk. Selanjutnya penghulu baru mengantarkan carano kepada seluruh penghulu pucuk yang ada di nagari termasuk kepada Wali nagari dan Ketua KAN. Seluruh penghulu dan perangkatnya diundang pada pesta peresmian gelar, serta Wali Nagari dan Wali Korong juga turut diundang. Tahapan selanjutnya ialah menetukan tanggal 
pesta peresmian gelar penghulu baru tersebut.

Namun, setelah penentuan tanggal peresmian gelar penghulu tersebut terjadi konflik di dalam suku. Konflik dalam masyarakat Minangkabau disebut dengan kusuik (Jamil, 2020). Dalam pengangkatan penghulu di Nagari Kapalo Hilalang terjadi konlik yang diistilahkan dengan kusuik tali yaitu perselisihan atau sengketa yang terjadi antara satu keluarga dengan keluarga lain, antara jiran dengan tetangga, dan antara kaum pasukuan dengan pasukuan lain.

Ketika penghulu sudah disahkan atau setelah prosesi bagatok pinang muncullah gugatan dari beberapa anak kemenakan di dalam suku koto. KAN memberikan waktu tenggang untuk kembali bermusyawarah dalam kaum tersebut. Namun permasalahan semakin pelik karena anggota kaum tidak menemukan solusi atau kata mufakat. Hal ini disebabkan pihak yang tidak setuju memandang bahwa penghulu baru ini tidak kompeten dalam memimpin. Konflik ini berakhir dengan pembatalan acara peresmian gelar Datuk.

Berdasarkan wawancara dengan ketua KAN, mereka berpendapat bahwa permasalahan dalam kaum adalah masalah internal dan KAN tidak berwenang untuk menyelesaikannya. Hal ini sebenarnya tidak tepat, karena di beberapa daerah seperti di Riau, KAN dapat berperan dalam penyelesaian konflik, misalnya dengan ikut mendampingi masyarakat yang berkonflik dan turun langsung ke lokasi. (Bachtiar, 2017). KAN merupakan tempat terakhir dalam resolusi konflik melalui nilai dan institusi adat (Yuhelna, 2014.

\section{KESIMPULAN}

Prosesi pengangkatan Penghulu di Nagari Kapalo Halalang Kecamatan 2X11 Kayu Tanam, Kabupaten Padang Pariaman diawali dengan musyawarah kaum, untuk selanjutnya dibawa kepada kaum yang lebih besar. Jika seluruhnya sepakat maka diantarkanlah sirih kepada seluruh Penghulu Pucuk yang ada di dalam Nagari. Namun, konflik terjadi ketika ada pihak di dalam suku yang tidak setuju dengan terpilihnya penghulu baru tersebut. Alasannya disebabkan kurang cakapnya calon penghulu ini dalam memimpin, sehingga dikhawatirkan anak kemanakan akan terbengkalai masa depannya. KAN juga lepas tangan dan mengembalikan permasalahan ini kepada kaum suku koto. Padahal, tugas KAN adalah menyelesaikan sengketa adat yang terjadi di dalam suku, seperti yang terjadi dalam kasus pengangkatan penghulu ini. Fungsi KAN ini bertujuan agar dapat menciptakan kerukunan di dalam masyarakat dan kelestarian adat dapat terjaga dengan baik.

\section{DAFTAR PUSTAKA}

Bachtiar, M. (2017). Peranan Lembaga Adat Melayu Riau Dalam Penyelesaian Konflik Tanah Ulayat di Provinsi Riau. Jurnal Hukum Respublica, 16(2), 298312.

Jamil, M. (2020). KONFLIK DAN PENGHULU; Pendekatan

Mediasi Dalam Menyelesaikan

Konflik Internal Kaum Oleh Penghulu Di Minangkabau. TATHWIR: Jurnal Pengembangan Masyarakat Islam, 11(1), 47-59 
Marthala, A. E. (2014). Penghulu dan Filosofi Pakaian Kebesaran: Konsep Kepemimpinan Tradisional Minangkabau.

Rahmat, P. (2020). Konflik Kepengurusan Kerapatan Adat Nagari (Kan) Lubuk Kilangan Periode 2017-2022 (Doctoral Dissertation, Universitas Andalas).

Safitri, Ilmiawati. 2019. "Keraton Yogyakarta Masa Lampau dan Masa Kini: Dinamika Raja-raja Jawa dan Politik Wacana Raja Perempuan". Jurnal Indonesian Historical Studies, Vol. 3 No. 1
Sari, Putri Maya. 2014. "Kepemimpinan

Baru Dalam Suku Di

Minangkabau". Jurnal

Pendidikan sosiologi.

Soekanto, S. (2014). Sosiologi suatu pengantar.

Yuhelna, Y. Resolusi Konflik Berbasis Adat Studi Resolusi Konflik Harta Pusaka Tinggi Di Nagari Gantuang Ciri, Kab. Solok, Sumatera Barat. Jurnal Ilmu Sosial Mamangan,3(2), 5266. 